\title{
Sympatry between species of Juliomys (Rodentia: Sigmodontinae) along an altitudinal gradient in the Serra da Bocaina National Park
}

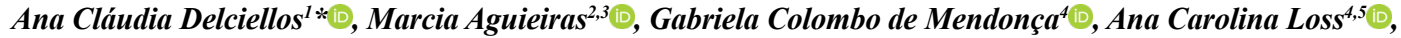 \\ Oscar Rocha-Barbosa ${ }^{6}$ \& Lena Geise ${ }^{3}$ \\ ${ }^{1}$ Universidade do Estado do Rio de Janeiro, Instituto de Biologia, Departamento de Ecologia, Programa de \\ Pós-Graduação em Ecologia e Evolução, Rua São Francisco Xavier, $n^{\circ}$ 524, Maracanã, 20550-900, Rio de \\ Janeiro, RJ, Brasil. \\ ${ }^{2}$ Universidade do Estado do Rio de Janeiro, Programa de Pós-Graduação em Meio Ambiente, Rua São \\ Francisco Xavier, $n^{\circ}$ 524, Maracanã, 20550-900, Rio de Janeiro, RJ, Brasil. \\ ${ }^{3}$ Universidade do Estado do Rio de Janeiro, Instituto de Biologia, Departamento de Zoologia, Laboratório de \\ Mastozoologia. Rua São Francisco Xavier 524, Maracanã, 20550 900, Rio de Janeiro, RJ, Brasil. \\ ${ }^{4}$ Universidade Federal do Espírito Santo, Departamento de Ciências Biológicas, Laboratório de Mastozoologia \\ e Biogeografia, Avenida Fernando Ferrari, 514, Goiabeiras, 29075-910, Vitória, ES, Brasil. \\ ${ }^{5}$ Museu de Biologia Professor Mello Leitão, Instituto Nacional da Mata Atlântica, Av. José Ruschi, 4, Centro, \\ 29650-000, Santa Teresa, ES, Brasil. \\ ${ }^{6}$ Universidade do Estado do Rio de Janeiro, Instituto de Biologia, Laboratório de Zoologia de Vertebrados - \\ Tetrapoda, Rua São Francisco Xavier 524, Maracanã, 20550-900, Rio de Janeiro, RJ, Brasil. \\ ${ }^{*}$ Corresponding author: Ana C. Delciellos, e-mail: anadelciellos@yahoo.com.br
}

DELCIELlOS, A.C., AGUIEIRAS, M., MENDONÇA, G.C., LOSS, A.C., ROCHA-BARBOSA, O., GEISE, L. Sympatry between species of Juliomys (Rodentia: Sigmodontinae) along an altitudinal gradient in the Serra da Bocaina National Park. Biota Neotropica 20(3): e20200958. https://doi.org/10.1590/1676-0611-BN-2020-0958

\begin{abstract}
The altitudinal gradient found in the Atlantic Forest may play a role in establishing sympatry areas between congeneric species of sigmodontine rodents. For some genera with cryptic species, the elucidation of spatial patterns of distribution may be useful to understand reproductive isolation and speciation patterns, as well as spatial and temporal factors determining the boundaries of species' geographical distributions. Here we evaluated the occurrence of sympatry between Juliomys species along an altitudinal gradient in the Serra da Bocaina National Park (SBNP). Additionally, we review the occurrence of J. rimofrons and add new records of species occurrence in the SBNP, aided by karyological and molecular data. The study was carried out at four sites in the SBNP, which ranged between 770 and 1,200 $\mathrm{m}$ a.s.l. We captured 24 Juliomys specimens. Six out of 24 specimens were collected and karyotyped. For $J$. pictipes, the karyotype had a $2 \mathrm{n}$ of 36 and a FN of 34, and for J. ossitenuis $2 \mathrm{n}$ of 20 and FN of 36 . Seventeen out of 24 Juliomys specimens were used in the cytochrome b phylogeny: 12 specimens grouped with J. pictipes and five with $J$. ossitenuis. Additionally, a specimen previously identified as J. rimofrons (MN 77793) clustered together with J. pictipes. Juliomys pictipes and J. ossitenuis were found in sympatry in two out of four sites in altitudes higher than 1,000 $\mathrm{m}$ a.s.1.. Our karyological and molecular data provided the detection of two Juliomys species in the SBNP for the first time (J. pictipes and J. ossitenuis) and disregarded the previous record of J. rimofrons. Our record of sympatry between $J$. pictipes and $J$. ossitenuis represents the fifth known record of sympatry between these species up to date. Keywords: Atlantic Forest; karyotype; mammals; phylogeny; Protected Area.
\end{abstract}

\section{Simpatria entre espécies de Juliomys (Rodentia: Sigmodontinae) ao longo de um gradiente altitudinal no Parque Nacional Serra da Bocaina}

Resumo: O gradiente altitudinal encontrado na Mata Atlântica pode desempenhar um papel no estabelecimento de áreas de simpatria entre espécies congêneres de roedores sigmodontíneos. Para alguns gêneros com espécies crípticas, a elucidação de padrões espaciais de distribuição pode ser útil para entender os padrões de isolamento reprodutivo e de especiação, bem como fatores espaciais e temporais que determinam os limites das distribuições geográficas das espécies. Aqui, avaliamos a ocorrência de simpatria entre as espécies de Juliomys ao longo de um gradiente altitudinal no Parque Nacional da Serra da Bocaina (SBNP). Além disso, revisamos a ocorrência de J. rimofrons e adicionamos novos registros de ocorrência de espécies no SBNP, auxiliados por dados cariológicos e moleculares. O estudo foi realizado em quatro locais no SBNP, que variaram entre 770 e $1.200 \mathrm{~m}$ a.n.m.. Foram capturados 24 espécimes de Juliomys. Seis dos 24 espécimes foram coletados e cariotipados. Para J. pictipes, o cariótipo tinha 2 n de 36 e um NF de 34, e para J. ossitenuis 2n de 20 e NF de 36. Dezessete dos 24 espécimes de Juliomys foram utilizados na filogenia do citocromo b: 12 espécimes agruparam com $J$ pictipes e cinco com $J$. ossitenuis. 
Além disso, um espécime previamente identificado como J. rimofrons (MN 77793) se agrupou com J. pictipes. Juliomys pictipes e $J$. ossitenuis foram encontrados em simpatria em dois dos quatro locais em altitudes superiores a 1.000 m a.n.m.. Nossos dados cariológicos e moleculares forneceram a detecção de duas espécies de Juliomys no SBNP pela primeira vez (J. pictipes e $J$. ossitenuis) e desconsideraram o registro anterior de $J$. rimofrons. Nosso registro de simpatria entre $J$. pictipes e $J$. ossitenuis representa o quinto registro de simpatria entre essas espécies conhecido até o momento.

Palavras-chave: Cariótipo; Filogenia; Mamíferos; Mata Atlântica; Unidade de Conservação.

\section{Introduction}

Juliomys encompasses Neotropical arboreal rodent species endemic to the southeastern Atlantic Forest of Brazil, with its northernmost distribution limited by the Doce River, in the state of Minas Gerais (González et al. 2015). The genus was described by González (2000) to allocate Juliomys pictipes (Osgood, 1933), originally described almost 70 years earlier as Thomasomys pictipes, later relocated to the genus Wilfredomys by Musser \& Carleton (1993). Thenceforth, three additional species were described for the genus: Juliomys rimofrons Oliveira \& Bonvicino, 2002, Juliomys ossitenuis Costa, Pavan, Leite \& Fagundes, 2007, and more recently Juliomys ximenezi Christoff, Vieira, Oliveira, Gonçalves, Valiati \& Tomasi, 2016 (Christoff et al. 2016). Recently, Juliomys was formally included in the tribe Wiedomyini Reig, 1980, which also includes Wiedomys, Wilfredomys, and Phaenomys (Gonçalves et al. 2020). All living species of Juliomys are associated with well-preserved voucher specimens, cytochrome b sequences and unique karyotypes, which facilitate species diagnoses (D'Elía et al. 2007). However, Juliomys includes cryptic species, not easily recognized in the field by their external morphological characters (Christoff et al. 2016). The few existing studies that differentiated species through external morphological characters found different morphological patterns in different localities, suggesting possible geographical variation in some of the characters commonly used (Pavan \& Leite 2011, Aguieiras et al. 2013).

Some congeneric species of Neotropical rodents may occur in sympatry (i.e., two species occupying the same locality) or even in syntopy (i.e., two species occupying the same locality at the same time) (Gannon 1998, Gonçalves \& Oliveira 2004, Cordeiro-Estrela et al. 2008, Mallet et al. 2009, Delciellos et al. 2018a). Studies on these species may be useful to better understand reproductive isolation and speciation patterns (Noor 1999), as well as ecological processes such as spatial (e.g., microhabitat selection) and temporal (e.g., divergence time) factors determining the boundaries of species' geographical distributions (Laiolo et al. 2017). Juliomys pictipes, the most widespread species of the genus (González et al. 2015), may present some overlapping with the known geographic distribution area of all other species (González et al. 2015, Christoff et al. 2016), but only four sympatric occurrences between J. pictipes and J. ossitenuis have been recorded so far.
Sympatry between these two species was recorded in the municipalities of Caucaia do Alto (Morro Grande Forest Reserve), Mulheres, and Museros in the state of São Paulo (800 - 1000 m a.s.l.; Costa et al. 2007, Pavan \& Leite 2011), and in the municipality of Teresópolis (Serra dos Órgãos National Park), in the state of Rio de Janeiro (1,200 m a.s.l.; Aguieiras et al. 2013). These records suggest that sympatry areas between these two species may occur at altitudes above $800 \mathrm{~m}$ a.s.l., as all localities of $J$. ossitenuis known so far are at higher altitudes (> $800 \mathrm{~m})$, while $J$. pictipes are recorded in a broader altitudinal range (Costa et al. 2007, Pardiñas et al. 2008, Cerboncini et al. 2014).

Here we evaluated the occurrence of sympatry between Juliomys species along an altitudinal gradient in the Serra da Bocaina National Park. Additionally, we review the occurrence of $J$. rimofrons and add new records of species occurrence in the park, aided by karyological and molecular data.

\section{Material and Methods}

\section{Study area}

The Serra da Bocaina National Park (SBNP) is one of the few remaining large fragments of Atlantic Forest, and has an altitudinal gradient that ranges from 0 to $2,088 \mathrm{~m}$ a.s.1.. The first study regarding mammal species that occur in the park was published in 2012 (Delciellos et al. 2012). Since then some other rodent and bat species had their occurrence recorded for the first time in the SBNP and also in the state of Rio de Janeiro, such as Drymoreomys albimaculatus (Delciellos et al. 2015), Phyllomys sulinus (Delciellos et al. 2018a), and Trinycteris nicefori (Delciellos et al. 2018b). Regarding Juliomys, only a single specimen was previously captured in the park and firstly identified as $J$. rimofrons by external and dental morphology using diagnostic characteristics (Delciellos et al. 2012, Fonseca et al. 2013). The park encompasses areas of potential occurrence of all Juliomys species, except J. ximenezi (Christoff et al. 2016).

Field work was carried out at four sites in the municipality of Paraty, state of Rio de Janeiro, Brazil, along the state highway RJ-165 that crosses the SBNP (Figure 1). Sites range between 770 and $1,200 \mathrm{~m}$ a.s.l. (Table 1 ). The climate in the municipality of Paraty has a rainy season between October and April, and a drier season between May and September, with a mean annual precipitation of 2,284 $\mathrm{mm}$ and a mean annual temperature of $23.3^{\circ} \mathrm{C}$ (Climate-Data.Org 2019). The vegetation is classified as dense montane rainforest (Delciellos et al. 2018a,b). 

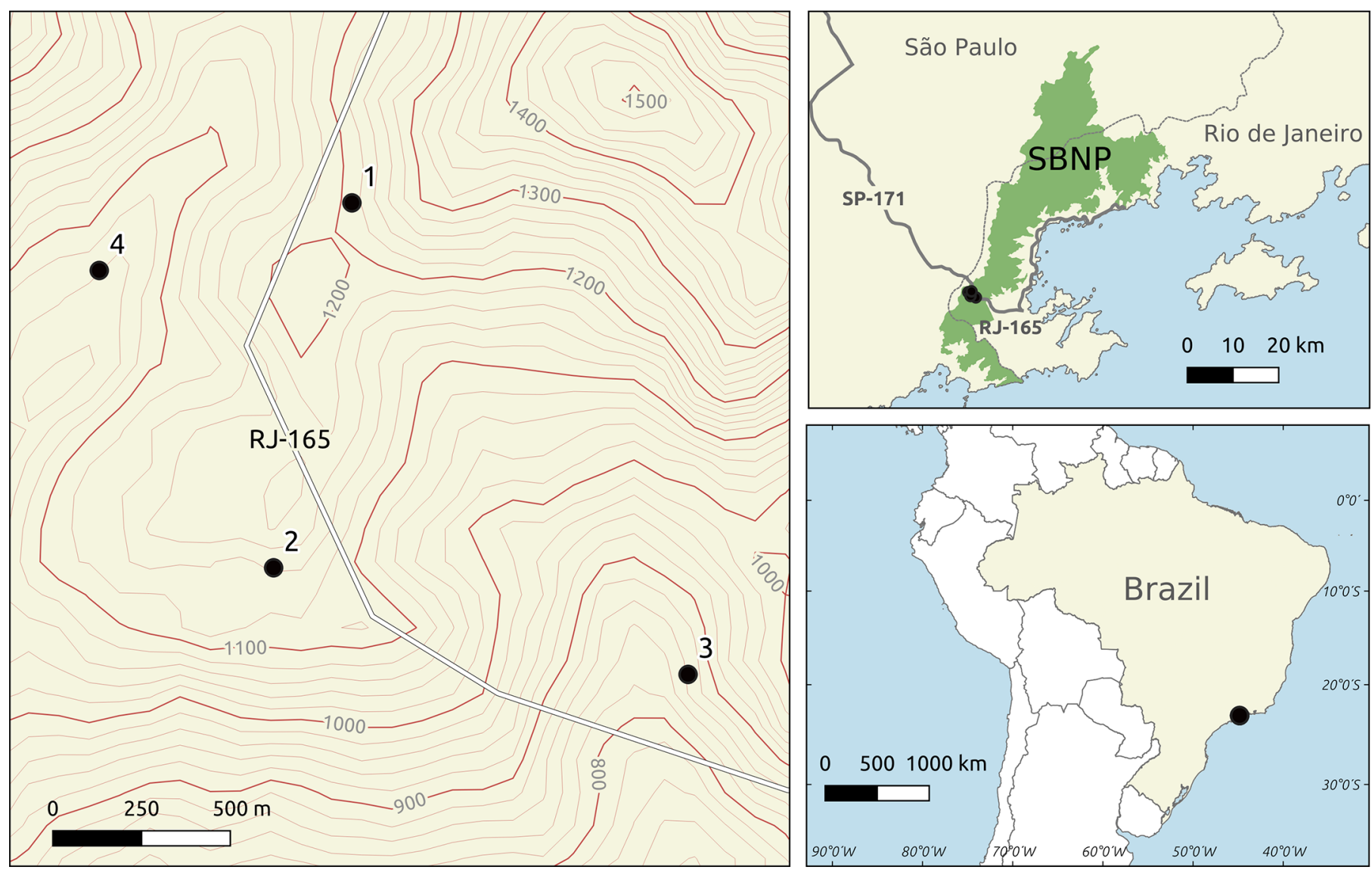

Figure 1. Collection localities of Juliomys (Rodentia: Sigmodontinae) specimens at the Serra da Bocaina National Park (SBNP). Localities numbers correspond to sites listed in Table 1.

Table 1. List of Juliomys (Rodentia: Sigmodontinae) specimens from which karyotype and/or cytochrome b sequence data were obtained from the Serra da Bocaina National Park, municipality of Paraty, state of Rio de Janeiro, Brazil. MN = Collected specimens deposited at the Museu Nacional, Universidade Federal do Rio de Janeiro, Rio de Janeiro, Brazil; BOCA = Field number from not collected specimens in the present study.

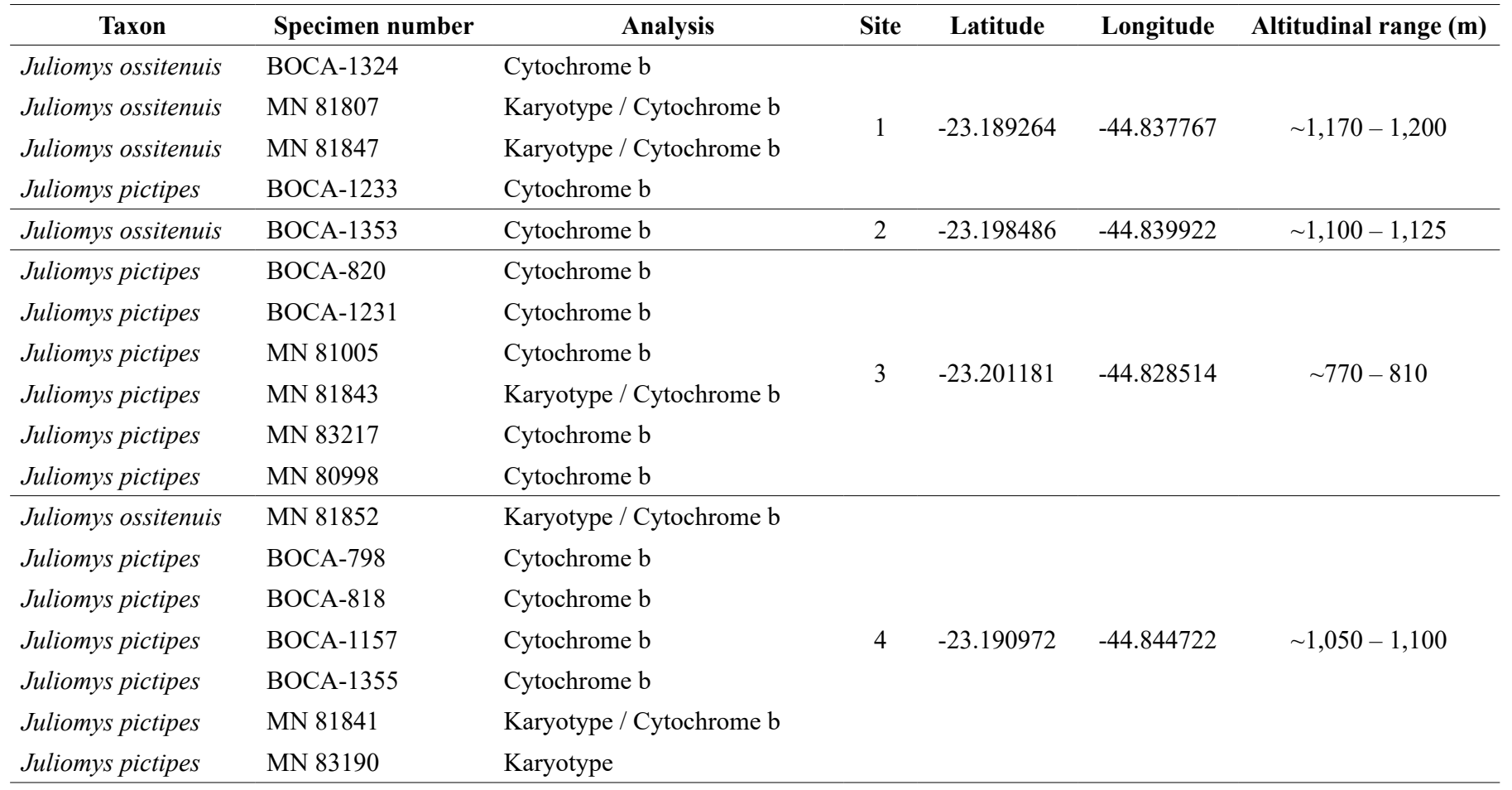




\section{Sampling of small mammals}

Non-volant small mammals were sampled in twelve trap sessions from June 2013 to December 2016 with live and pitfall traps (IBAMA/MMA process no. 02001.003937/2008-18, authorization n. 248/2013 and 610/2015). At each site, two $290 \mathrm{~m}$ long transects were established, each with 30 trap stations, $10 \mathrm{~m}$ apart. At each transect, odd trap stations $(\mathrm{N}=15)$ had a Tomahawk ${ }^{\circledR}$ placed on the floor; and even trap stations $(\mathrm{N}=15)$ and the first 10 odd trap stations $(\mathrm{N}=10)$ had a Sherman $({ })$ in the understory between 1.5 and $2.5 \mathrm{~m}$ above ground. Tomahawk traps were baited with a mixture of banana, bacon, grinded peanut and oat, and Sherman traps with slices of banana. A sampling effort of 18,997 traps-night was carried out for livetraps.

Pitfall-traps, with 60 liters plastic buckets placed $10 \mathrm{~m}$ apart were arranged in transects with three to ten buckets, according to terrain characteristics, such as inclination and amount of rocks. Buckets were connected by a plastic-sheet drift fence $0.5 \mathrm{~m}$ high, buried $0.1 \mathrm{~m}$ below and extended perpendicularly to the ground, to induce the capture of wandering specimens. Each of the four sites had twenty buckets. For pitfalls, the sampling effort was 4,591 buckets-night.

Live and pitfall-traps remained active for five consecutive nights in each trap session. Trapped specimens were weighed using spring scales, sexed, measured (heady-body and tail lengths), and marked with a numbered ear-tag at the first capture (Ear tags, National Band \& Tag Co., Newport, Kentucky, USA). In the field, specimens were identified as belonging to the genus Juliomys according to a set of external morphological characteristics, such as small size among sigmodontines, tail longer than the body, long pelage, orangish top of the head and on the rump, toes covered with whitish hairs, and short rostrum, as described by Bonvicino et al. (2008) and González et al. (2015). Collected specimens were prepared as vouchers and deposited at the Museu Nacional, Universidade Federal do Rio de Janeiro, Brazil. Specimens were handled following protocols approved by the American Society of Mammalogists (Sikes \& Animal Care and Use Committee of the American Society of Mammalogists 2016).

\section{Karyotypic and molecular analysis}

Chromosomes in metaphases from six specimens (Table 1) were obtained with in vitro culture following Geise (2014) with modifications - culture kept at $36.5^{\circ} \mathrm{C}$ for $1 \mathrm{~h} 40 \mathrm{~min}$. Slides with the karyotype preparation, stained with Giemsa $5 \%$, were used to observe diploid (2n), fundamental autosomal numbers (FN), and chromosome morphology. Microscopic analyzes were done on the optic photomicroscope (Nikon Eclipse 50i), increase of 1,000 - immersion objective of 100 plus 10 ocular lenses. Karyotypes were assembled in descending order of chromosome size, two-arm chromosomes first, followed by acrocentric chromosomes, and compared with the literature. Karyotypes preparation and slides were deposited in the collection of the Laboratório de Mastozoologia, Universidade do Estado do Rio de Janeiro, Brazil.
Mitochondrial DNA of 17 Juliomys specimens was sequenced to help the correct identification of specimens (Table 1). Additionally, the $J$. rimofrons specimen (MN 77793) previously recorded in the study area (Delciellos et al. 2012, Fonseca et al. 2013) were also included in the analyses. Total genomic DNA was extracted from liver and epithelial tissue using the salt protocol and proteinase K (Bruford et al. 1992). The polymerase chain reaction (PCR) was performed using primers MVZ05 (5'-CGAAGCTTGATATGAAAAACCATCGTTG-3') and MVZ16 (5'-AAATAGGAARTATCAYTCTGGTTTRAT-3') (Smith \& Patton 1993) for amplification of the first 801 pairs base (bp) of the mitochondrial cytochrome b gene (Cytb). For each PCR with a final volume of $10.0 \mu \mathrm{l}$ were added $6.8 \mu \mathrm{L}$ of ddH $\mathrm{O}_{2} \mathrm{O}, 1.0 \mu \mathrm{L}$ of buffer $10 \times, 0.5 \mu \mathrm{L}$ of $\mathrm{MgCl}_{2}(50 \mathrm{mM}), 0.2 \mu \mathrm{L}$ of dNTP solution (10 mM each nucleotide), $0.2 \mu \mathrm{L}$ of each forward and reverse primer (10 $\mu \mathrm{M}), 0.1 \mu \mathrm{L}$ of Taq Platinum (Invitrogen Corporation) $(5 \mathrm{U} / \mu \mathrm{L}$ ) and $1.0 \mu \mathrm{L}$ of DNA (40 ng/ $\mu \mathrm{L})$. For amplification the samples were exposed to the following conditions: initial denaturation at $94^{\circ} \mathrm{C}$ for 5 min, 39 cycles of annealing at $94^{\circ} \mathrm{C}$ for $30 \mathrm{sec}$, extension at $48^{\circ} \mathrm{C}$ for $45 \mathrm{sec}$ and extension at $72^{\circ} \mathrm{C}$ for $45 \mathrm{sec}$, followed by a final extension step at $72^{\circ} \mathrm{C}$ for $5 \mathrm{~min}$.

PCR products were purified with ExoSAP enzyme (GE Healthcare Life Sciences) and the sequencing reaction was performed with Big Dye v3.1 kit (Applied Biosystems) following the manufacturer's protocol. Subsequently, samples were sequenced in one direction only, using forward primer MVZ05 at ABI 3500 automated sequencer. Sequences were manually edited and aligned using ClustalW algorithm implemented in Molecular Evolutionary Genetics Analysis software (MEGA 7) (Kumar et al. 2017). We also included in the alignment 18 sequences obtained from GenBank (http://www.ncbi.nlm.nih. gov/genbank/) (Table 2). We performed phylogenetic analyses using Maximum Likelihood (ML) with GTR + G (General Time Reversible + Gamma) substitution model. Nodal supports were evaluated using 100 bootstrap pseudoreplicates. Phylogenetic analyses were generated using RAxML v 8.2.9 software (Stamatakis 2014) at CIPRES platform (http://www.phylo. org/index.php). Only groups that presented bootstrap support equal to or above $70 \%$ were considered to be robust. Rhagomys rufescens and Wiedomys cerradensis sequences, taken from GenBank (http://www.ncbi.nlm.nih.gov/genbank/), were used as external groups (Table 2). The phylogeny obtained was edited manually using Figtree v1 4.3 (Rambaut 2016) and Inkscape 0.92 .1 (https://inkscape.org/en/).

\section{Results}

Thirty-five species of non-volant small mammals were recorded from a total of 1,222 captured specimens. Twenty-four from these 1,222 specimens $(2 \%)$ belong to the genus Juliomys, and six from these 24 specimens were collected, karyotyped and prepared as voucher specimens: three females (MN 81841, MN 81843, and MN 83190) were identified as J. pictipes, and two males and one female (MN 81807, MN 81847, and MN 81852) as J. ossitenuis (Table 1). 
Table 2. List of Sigmodontinae specimens from which cytochrome $\mathrm{b}$ sequence data was used for phylogenetic analyses. * Holotype; ** Paratype. BOCA $=$ Field number from not collected specimens in the present study. Zoological collections: AB = Museu de Zoologia, Universidade de São Paulo, São Paulo, Brazil (uncatalogued); MBML = Museu de Biologia Mello Leitão, Santa Teresa, Brazil; MCNU = Museu de Ciências Naturais, Universidade Luterana do Brazil, Canoas, Brazil; MLP = Museo de La Plata, Buenos Aires, Argentina; MN = Museu Nacional, Universidade Federal do Rio de Janeiro, Rio de Janeiro, Brazil; MZUSP = Museu de Zoologia, Universidade de São Paulo, São Paulo, Brazil; TK = Museum of Texas Tech University, USA; UFMG = Universidade Federal de Minas Gerais, Belo Horizonte, Brazil; UFPB = Universidade Federal da Paraíba, Brazil.




For J. pictipes, the karyotype had a $2 \mathrm{n}$ of 36 and a $\mathrm{FN}$ of 34 , and for $J$. ossitenuis $2 \mathrm{n}$ of 20 and $\mathrm{FN}$ of 36 (Figure 2). The autosomal complement of $J$. pictipes was composed only by acrocentric chromosomes in decreasing size and the $\mathrm{X}$ chromosome was a medium acrocentric. The karyotype of J. ossitenuis was composed of six metacentric and three submetacentric chromosome pairs. The $\mathrm{X}$ chromosome was a submetacentric and the $\mathrm{Y}$ an acrocentric. In the Cytb phylogeny, 12 specimens grouped with J. pictipes, and five with $J$. ossitenuis (Table 2; Figure 3). The specimen previously identified as $J$. rimofrons (MN 77793) clustered together with J. pictipes (Figure 3).

Two Juliomys specimens were captured with Sherman traps placed in the understory, and $91.7 \%(\mathrm{~N}=22)$ of captures occurred on pitfalls. Specimens of J. pictipes were captured in sites 1, 3 and 4, in altitudes ranging from 770 to $1,200 \mathrm{~m}$ a.s.l. (Table 3). For this species, the highest number of captures occurred in sites 3 and 4 , with six captures each. Specimens of $J$. ossitenuis were captured in sites 1,2, and 4, in altitude ranging from 1,050 to $1,200 \mathrm{~m}$ a.s.l. (Table 3 ). For this species, most specimens ( 3 out of 5) were captured in site 1, which is the site with the highest altitude. Sympatry between these two Juliomys species occurred on sites 1 and 4 (Table 3). Also, in trap sessions 7 (January 2015) and 10 (February 2016) both species were captured, but not at the same site (Table 3 ).

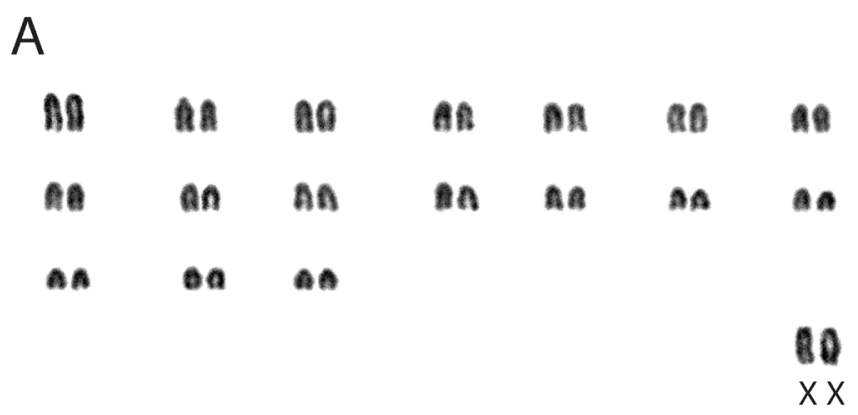

B

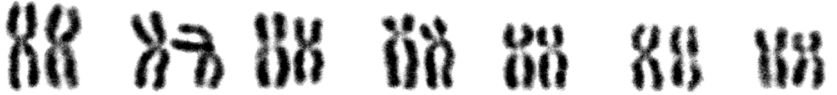

\section{8 in}

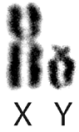

Figure 2. Conventional staining of the karyotypes of Juliomys pictipes (A-MN 83190, female) and Juliomys ossitenuis (B - MN 81807, male), showing $2 \mathrm{n}=$ $36, \mathrm{FN}=34$ and $2 \mathrm{n}=20, \mathrm{FN}=36$, respectively.

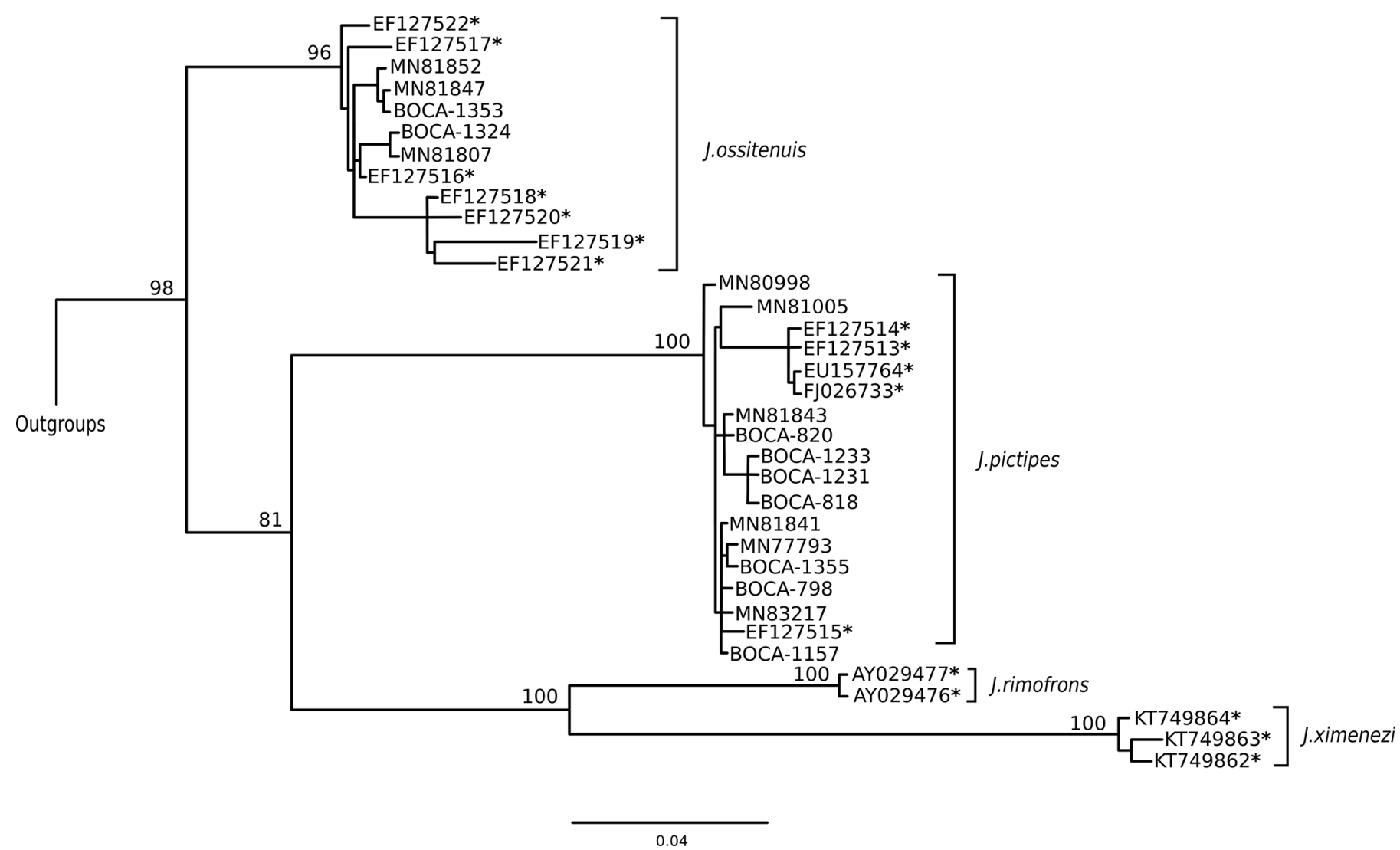

Figure 3. Phylogenetic relationships among Juliomys (Rodentia: Sigmodontinae) species based on maximum likelihood using 801 base pairs of cytochrome $b$ (Cytb) gene under GTR + G model of sequence evolution. Bootstrap support values ( $>70 \%)$ from maximum likelihood are indicated in the nodes. Specimens from GenBank are followed by asterisk. Scale bar corresponds to the mean number of nucleotide substitutions per site. 
Table 3. Occurrence of Juliomys pictipes (JP) and Juliomys ossitenuis (JO) (Rodentia: Sigmodontinae) during trap sessions carried out from June 2013 to December 2016 along an altitudinal gradient at the Serra da Bocaina National Park, municipality of Paraty, state of Rio de Janeiro, Brazil. Sympatry between these two species occurred on sites 1 and 4 . In trap sessions 7 and 10 both species were captured, but not at the same site. Trap sessions: $1=$ June 2013; $2=$ September $2013 ; 3=$ December 2013; 4 = April 2014; 5 = June 2014; 6 = October 2014; 7 = January 2015; $8=$ October 2015; $9=$ December 2015; $10=$ February 2016; 11 = July 2016; $12=$ December 2016

\begin{tabular}{|c|c|c|c|c|c|c|c|c|c|c|c|c|c|}
\hline \multirow{2}{*}{ Site } & \multirow{2}{*}{ Altitudinal range ( $m$ a.s.l.) } & \multicolumn{12}{|c|}{ Trap sessions } \\
\hline & & 1 & 2 & 3 & 4 & 5 & 6 & 7 & 8 & 9 & 10 & 11 & 12 \\
\hline 1 & $\sim 1,170-1,200$ & & & & JO & & & $\mathrm{JO}$ & & $\mathrm{JP}$ & $\mathrm{JO}$ & & \\
\hline 4 & $\sim 1,050-1,100$ & & & & $\mathrm{JO}$ & & JP & JP & JP & & JP & & \\
\hline 3 & $\sim 770-810$ & JP & & & & & & $\mathrm{JP}$ & JP & JP & & & \\
\hline
\end{tabular}

\section{Discussion}

The karyological and molecular analyses carried out provided the detection of two Juliomys species in the SBNP for the first time: J. pictipes and J. ossitenuis. On the other hand, the previous record of J. rimofrons in the park (site 3 ) based on the specimen MN 77793 (Delciellos et al. 2012, Fonseca et al. 2013) should be disregarded, as this specimen is actually a J. pictipes and not J. rimofrons according to our molecular analyses results. Thus, we confirmed the occurrence of only two Juliomys species in the park. Additionally, J. pictipes and J. ossitenuis co-occurred in two out of four sites with altitudes higher than $1,000 \mathrm{~m}$ a.s.l., representing the fifth known record of sympatry between these species up to date.

The first studies carried out at the SBNP evidenced the occurrence of J. rimofrons in the park (Delciellos et al. 2012, Fonseca et al. 2013). Fonseca et al. (2013) used solely external and dental morphology for species identification, which were based mainly on the presence of the interfrontal fontanelle and small ectolophid and ectostylid of lower molars $\mathrm{m} 1$ and $\mathrm{m} 2$. These are well-established characters that can be used to differentiate $J$. rimofrons from the other three Juliomys species (Costa et al. 2007, Christoff et al. 2016). However, in the present study the specimen previously identified as $J$. rimofrons (MN 77793) by Fonseca et al. (2013) clustered with J. pictipes in the phylogeny based on cytochrome $b$ sequences. Thus, the occurrence of J. rimofrons in the Serra da Bocaina remains to be confirmed in future studies, as well as the species identification of the second $J$. rimofrons specimen (MN 76236) analyzed by Fonseca et al. (2013), collected at the municipality of São José do Barreiro, State of São Paulo, has not yet been confirmed through molecular analyzes. The phylogeny based on cytochrome $\mathrm{b}$ sequences also allowed the first record of $J$. pictipes and $J$. ossitenuis in the park. Karyotypes found by us for J. pictipes (Bonvincino \& Otazu 1999, Aguieiras et al. 2013, Di-Nizo et al. 2014) and J. ossitenuis (Costa et al. 2007, Paresque et al. 2009, Aguieiras et al. 2013) are in accordance with the literature.

Since Poulton (1904) coined the term "sympatry", its meaning has been extensively debated by ecologists (see discussion in Mallet et al. 2009). Here sympatry was defined as the cooccurrence of species in the same locality, in which individuals of both species may encounter one another with frequency but there may be an ecological segregation between them (i.e., species have different niche requirements) (Mallet et al. 2009).
Sympatry between $J$. pictipes and $J$. ossitenuis in the SBNP was detected in sites above $1,050 \mathrm{~m}$ a.s.l. where both species were expected to occur according to our results and those of previous studies (Costa et al. 2007, Pardiñas et al. 2008, Cerboncini et al. 2014).

Juliomys ossitenuis is an endemic species of high altitudes $(>800 \mathrm{~m})$ in the Brazilian Atlantic Forest, while J. pictipes is endemic to the Atlantic Forest but with a larger extent of occurrence than $J$. ossitenuis, inhabiting altitudes that range from sea level to 2,000 m a.s.l. (Geise \& Pardiñas 2016). Thus, the altitudinal gradient observed in the Atlantic Forest may play a role in establishing sympatry areas between these species, because these areas are expected to occur only between 800 and 2,000 m a.s.l.. Several extrinsic factors vary along an altitudinal gradient, such as vegetation characteristics, temperature, precipitation, topography, and soil characteristics, among others (Graham et al. 2014). This complex environmental heterogeneity found in an altitudinal gradient can affect from individual's tolerance to abiotic factors (e.g., temperature) to community patterns of cooccurrence (e.g., species richness), being these spatial patterns of biodiversity extensively studied in community ecology (Graham et al. 2014, Willig \& Presley 2016). The specific factors that cause $J$. ossitenuis to occur only at high altitudes in the Atlantic Forest also remains to be evaluated in future studies.

Despite the recognized role of mountain systems to promote isolation and species diversification (Graham et al. 2014), $J$. pictipes and J. ossitenuis are not sister species (see Figure 3) and therefore these records of sympatry in the SBNP may represent a secondary contact zone. Pardiñas et al. (2008) also suggested a relatively old separation between these two species. The explanatory factors for the occurrence of sympatry between these species in the park were not evaluated in the present study because of the small data set available, but sympatry among similar or cryptic species frequently is possible due to habitat and diet partitioning (Mallet et al. 2009). Juliomys pictipes and $J$. ossitenuis specimens did not differ in forest strata where captures occurred in the present study, but these species may have different habitat preferences or behaviors related to the use of three-dimensional space that have not yet been clarified. Additionally, J. pictipes and J. ossitenuis seem not differ greatly in diet, with both species considered granivorous according to Galetti et al. (2015) and González et al. (2015).

Juliomys pictipes and J. ossitenuis can be considered as rare species in the communities where they occur (e.g., Pardini et al. 2005). 
This rarity in local communities was corroborated in the present study, as Juliomys specimens accounted for only $2 \%$ of captured specimens. This rarity of Juliomys species in small mammals' communities, associated with species misidentifications in the field using solely external morphological characteristics, and infrequent use of pitfalls traps by researchers, may be contributing with the few existing records of sympatry between these species.

\section{Acknowledgements}

We are in debt to the researchers who helped in fieldwork, mainly Lucas H. Possi, Natali C. Pineiro, and Priscilla L. Zangrandi. To Universidade do Estado do Rio de Janeiro-UERJ, Departamento de Estradas de Rodagem do Estado do Rio de Janeiro, and Secretaria de Obras/Governo do Rio de Janeiro for logistical support and general coordination of the Estrada Parque Paraty-Cunha RJ-165 Project. To José Maria and Pedro Oliveira for logistical support and assistance in the field work. We also thank three anonymous reviewers and the Associate Editor Diego Astúa for valuable comments on the manuscript. Financial support was provided by grants from Coordenação de Aperfeiçoamento de Pessoal de Nível Superior-CAPES/Programa de Excelência Acadêmica-Proex (process number 1631/2018). Ana C. Delciellos has a postdoctoral scholarship from CAPES (PNPD/PPGEEUERJ, process number 1631/2018) and Ana C. Loss from Conselho Nacional de Desenvolvimento Científico e Tecnológico-CNPq (process number 306772/2019-1). Marcia Aguieiras has a doctoral scholarship from CAPES. Gabriela C. Mendonça had an Institutional Program for Scientific Initiation-PIBIC scholarship from $\mathrm{CNPq}$ and a Master scholarship from Fundação de Amparo à Pesquisa e Inovação do Espírito Santo-FAPES. FAPES also provided funding for the project (FAPES process number 80600417). Lena Geise receives fellowship from $\mathrm{CNPq}$ and UERJ/Prociência and Oscar Rocha-Barbosa from UERJ/Prociência.

\section{Author Contributions}

Ana Cláudia Delciellos: Substantial contribution in the concept and design of the study; contribution to data collection; contribution to data analysis and interpretation; contribution to manuscript preparation; contribution to critical revision, adding intellectual content.

Marcia Aguieiras: Contribution to data collection; contribution to data analysis and interpretation; contribution to manuscript preparation; contribution to critical revision, adding intellectual content.

Gabriela Colombo de Mendonça: Contribution to data collection; contribution to data analysis and interpretation; contribution to manuscript preparation; contribution to critical revision, adding intellectual content.

Ana Carolina Loss: Contribution to data collection; contribution to data analysis and interpretation; contribution to manuscript preparation; contribution to critical revision, adding intellectual content.

Oscar Rocha-Barbosa: Substantial contribution in the concept and design of the study.

Lena Geise: Contribution to data collection; contribution to data analysis and interpretation; contribution to manuscript preparation; contribution to critical revision, adding intellectual content.

\section{Conflicts of Interest}

The authors declare that they have no conflict of interest related to the publication of this manuscript.

\section{References}

AGUIEIRAS, M., ALMEIDA, B., AZAMOR, L., BARBOSA, J.L., BEZERRA, A.C., CAMILO, K.C. \& GEISE, L. 2013. Primeiro registro de Juliomys ossitenuis Costa, Pavan, Leite and Fagundes, 2007 e simpatria com Juliomys pictipes (Osgood, 1933) (Rodentia, Cricetidae, Sigmodontinae) na Serra dos Órgãos, Rio de Janeiro. Bol. Soc. Bras. Mastozool. 68:57-64.

BONVICINO, C.R., OLIVEIRA, J.D., \& D'ANDREA, P.S. 2008. Guia dos roedores do Brasil, com chaves para gêneros baseadas em caracteres externos. Centro Pan-Americano de Febre Aftosa-OPAS/OMS, Rio de Janeiro.

BONVINCINO, C.R. \& OTAZU, I. 1999. The Wilfredomys pictipes (Rodentia: Sigmodontinae) karyotype with comments on the karyosystematics of Brazilian Thomasomyini. Acta Theriol. 44(3):329-332.

BRUFORD, M.W., HANOTTE, O., BROOKFIELD, J.F.Y. \& BURKE, T. 1992. Single-locus and DNA fingerprinting. In Molecular genetic analyses of populations: a practical approach (A.R. Hoelzel, ed.). IRL Press, Oxford. p.225-269.

CERBONCINI, R.A.S., JUNIOR, C.M.M., TIEPOLO, L.M. \& PASSOS, F.C. 2014. New records of the red-rumped mouse Juliomys pictipes (Osgood, 1933) (Rodentia: Sigmodontinae) in coastal Atlantic Forest of Paraná, southern Brazil. Biotemas 27(1):159-164.

CHRISTOFF, A.U., VIEIRA, E.M., OLIVEIRA, L.R., GONÇALVES, J.W., VALIATI, V.H. \& TOMASI, P.S. 2016. A new species of Juliomys (Rodentia, Cricetidae, Sigmodontinae) from the Atlantic Forest of Southern Brazil. J. Mamm. 97(5):1469-1482.

CLIMATE-DATA.ORG. 2019. https://pt.climate-data.org/ (last access in $25 / 08 / / 2019$ )

CORDEIRO-ESTRELA, P., BAYLAC, M., DENYS, C. \& POLOP, J. 2008. Combining geometric morphometrics and pattern recognition to identify interspecific patterns of skull variation: case study in sympatric Argentinian species of the genus Calomys (Rodentia: Cricetidae: Sigmodontinae). Biol. J. Linn. Soc. 94(2):365-378.

COSTA, L.P., PAVAN S.E., LEITE, Y.L.R. \& FAGUNDES, V. 2007. A new species of Juliomys (Mammalia: Rodentia: Cricetidae) from the Atlantic Forest of southeastern Brazil. Zootaxa 1463:21-37.

DE LA SANCHA, N., D’ELÍA, G., NETTO, F., PEREZ, P. \& SALAZARBRAVO, J. 2009. Discovery of Juliomys (Rodentia, Sigmodontinae) in Paraguay, a new genus of Sigmodontinae for the country's Atlantic Forest. Mammalia 73(2):162-167.

Delciellos, A.C., AGUieIRAS, M., GeISE, L., WEKSLER, M. \& ROCHA-BARBOSA, O. 2015. First record of Drymoreomys albimaculatus Percequillo, Weksler \& Costa, 2011 (Rodentia, Cricetidae, Sigmodontinae) in Rio de Janeiro state, Brazil. Check List 11(2):1572.

DELCIELLOS, A.C., LOSS, A.C., AGUIEIRAS, M., GEISE, L. \& ROCHABARBOSA, O. 2018a. Syntopy of cryptic Phyllomys (Rodentia: Echimyidae) species: description of the karyotype of Phyllomys nigrispinus and an expansion of the geographic distribution of Phyllomys sulinus. Mammalia 82(3):266-275.

DELCIEllos, A.C., MOTTA, A., DIAS, D., ALMEIDA, B. \& ROCHABARBOSA, O. 2018b. Bats of the Serra da Bocaina National Park, southeastern Brazil: an updated species list and a distribution extension for Trinycteris nicefori (Sanborn, 1949). Biota Neotrop. 18(4):e20180537.

DELCIELLOS, A.C., NOVAES, R.L.M., LOGUERCIO, M.F.L., GEISE, L., SANTOI, R.T., SOUZA, R., PAPI, B.S., RAÍCES, D., VIEIRA, N.R., FELIX, S., DETOGNE, N., SILVA, C.C.S., BERGALLO, H.G. \& ROCHABARBOSA, O. 2012. Mammals of Serra da Bocaina National Park, state of Rio de Janeiro, southeastern Brazil. Check List 8:675-692.

D’ELÍA, G., PARDIÑAS, U.F., TETA, P. \& PATTON, J.L. 2007. Definition and diagnosis of a new tribe of sigmodontine rodents (Cricetidae: Sigmodontinae), and a revised classification of the subfamily. Gayana 71(2):187-194. 
DI-NIZO, C.B., NEVES, C.L., VILELA, J.F. \& SILVA, M.J.J. 2014. New karyologycal data and cytotaxonomic considerations on small mammals from Santa Virgínia (Parque Estadual da Serra do Mar, Atlantic Forest, Brazil). Comp. Cytogenet. 8(1):11-30.

FONSECA, R., BERGALLO, H.G., DELCIELLOS, A.C., ROCHA-BARBOSA, O. \& GEISE, L. 2013. Juliomys rimofrons Oliveira and Bonvicino, 2002 (Rodentia: Cricetidae): distribution extension. Check List 9(3):684-685.

GALETTI, M., GUEVARA, R., NEVES, C. L., RODARTE, R. R., BOVENDORP, R. S., MOREIRA, M., HOPKINS III, J.B. \& YEAKEL, J.D 2015. Defaunation affects the populations and diets of rodents in Neotropical rainforests. Biol. Conserv. 190:2-7.

GANNON, W. L. 1998. Syntopy between two species of long-eared bats (Myotis evotis and Myotis auriculus). Southwest. Nat. 43:394-396.

GEISE, L. 2014. Procedimentos genéticos iniciais na captura e preparação de mamíferos. In Técnicas de estudos aplicadas aos mamíferos silvestres brasileiros (N.R. Reis, A.L. Peracchi, B.K. Rossaneis \& M.N. Fregonezi, eds.). Technical Books Editora Ltda, Rio de Janeiro. p.221-235.

GEISE, L. \& PARDIÑAS, U. 2016. Juliomys pictipes (errata version published in 2017). The IUCN Red List of Threatened Species 2016: e.T23078A115167037. https://dx.doi.org/10.2305/IUCN.UK.2016-3.RLTS. T23078A22330515.en. Downloaded on 21 April 2020.

GONÇALVES, P.R., CHRISTOFF, A.U., MACHADO, L.F., BONVICINO, C.R., PETERS, F.B. \& PERCEQUILLO, A.R. 2020. Unraveling deep branches of the Sigmodontinae tree (Rodentia: Cricetidae) in eastern South America. J. Mammal. Evol. 27:139-160.

GONÇALVES, P.R. \& OLIVEIRA, J.A. 2004. Morphological and genetic variation between two sympatric forms of Oxymycterus (Rodentia: Sigmodontinae): an evaluation of hypotheses of differentiation within the genus. J. Mamm. 85(1):148-161.

GONZÁLEZ, E.M. 2000. Un nuevo genero de roedor sigmodontino de Argentina y Brasil (Mammalia: Rodentia: Sigmodontinae). Comun. Zool. Mus. Hist. Nat. Montevideo 12(195):1-12.

GONZÁLEZ, E.M., OLIVEIRA, J.A. \& TETA, P. 2015. Genus Juliomys E. M González, 2000. In Mammals of South America, Volume 2: Rodents (J.L. Patton, U.F.J. Pardiñas \& G. D’Elía, eds.). University of Chicago Press, Chicago. p.92-96.

GRAHAM, C. H., CARNAVAL, A. C., CADENA, C. D., ZAMUDIO, K. R., ROBERTS, T. E., PARRA, J. L., MCCAIN, C.M., BOWIE, R.C.K., MORITZ, C., BAINES, S.B., SCHNEIDER, C.J., VANDERWAL, J., RAHBEK, C., KOZAK, K.H. \& SANDERS, N.J. 2014. The origin and maintenance of montane diversity: integrating evolutionary and ecological processes. Ecography 37(8):711-719.

KUMAR, S., STECHER, G. \& TAMURA, K. 2017. MEGA7: Molecular Evolutionary Genetics Analysis version 7.0 for bigger datasets. Mol. Biol. Evol. 33(7):1870-1874.

LAIOLO, P., SEOANE, J., OBESO, J.R. \& ILLERA, J.C. 2017. Ecological divergence among young lineages favours sympatry, but convergence among old ones allows coexistence in syntopy. Global Ecol. Biogeogr. 26(5):601-608.

MALLET, J., MEYER, A., NOSIL, P. \& FEDER, J.L. 2009. Space, sympatry and speciation. J. Evolution. Biol. 22(11):2332-2341.
MUSSER, G.G. \& CARLETON, M.D. 1993. Family Muridae. In Mammal Species of the World: a taxonomic and geographic reference (D.E. Wilson \& D.M. Reeder, eds.). Smithsonian Institution Press, Washington. p.501-755.

NOOR, M.A. 1999. Reinforcement and other consequences of sympatry. Heredity 83(5):503-508.

OLÍMPIO, A.P.M., COSTA, J.F., NASCIMENTO, D.C., CAMPOS, B.A., FRAGA, E.C. \& BARROS, M.C. 2016. Wiedomys cerradensis (Gonçalves, Almeida, Bonvicino, 2003) (Rodentia, Cricetidae): first record from the state of Maranhão, Brazil. Mammalia 80(1):97-101.

OLIVEIRA, J. A. \& BONVICINO, C.R. 2002. A new species of sigmodontine rodent from the Atlantic forest of eastern Brazil. Acta Theriol. 47(3):307-322.

PARDIÑAS, U.F., TETA, P., D’ELÍA, G. \& GALLIARI, C. 2008. Rediscovery of Juliomys pictipes (Rodentia: Cricetidae) in Argentina: emended diagnosis, geographic distribution, and insights on genetic structure. Zootaxa 1758:29-44.

PARDINI, R., SOUZA, S.M., BRAGA-NETO, R. \& METZGER, J.P. 2005. The role of forest structure, fragment size and corridors in maintaining small mammal abundance and diversity in an Atlantic forest landscape. Biol. Conserv. 124(2):253-266.

PARESQUE, R., CHRISTOFF, A.U. \& FAGUNDES, V. 2009. Karyology of the Atlantic forest rodent Juliomys (Cricetidae): A new karyotype from southern Brazil. Genet. Mol. Biol. 32(2):301-305.

PAVAN, S.E. \& LEITE, Y.L. 2011. Morphological diagnosis and geographic distribution of Atlantic Forest red-rumped mice of the genus Juliomys (Rodentia: Sigmodontinae). Zoologia 28(5):663-672.

PERCEQUILLO, A.R., GONÇALVES, P.R. \& OLIVEIRA, J.A. 2004. The rediscovery of Rhagomys rufescens (Thomas, 1886), with a morphological redescription and comments on its systematic relationships based on morphological and molecular (cytochrome b) characters. Mamm. Biol. 69(4):238-257.

POULTON, E.B. 1904. What is a species? Proc. Entomol. Soc. Lond. 1903:lxxvii-cxvi

RAMBAUT, A. 2016. Fig.Tree. Tree Figure Drawing Tool, version 1.4.0.

SIKES R.S. \& ANIMAL CARE AND USE COMMITTEE OF THE AMERICAN SOCIETY OF MAMMALOGISTS. 2016. Guidelines of the American Society of Mammalogists for the use of wild mammals in research and education. J. Mamm. 97:663-688.

SMITH, M.F. \& PATTON, J.L. 1993. The diversification of South American murid rodents: evidence from mitochondrial DNA sequence data for the akodontine tribe. Biol. J. Linnean Soc. 50:149-177.

STAMATAKIS, A. 2014. RAxML version 8: A tool for phylogenetic analysis and post-analysis of large phylogenies. Bioinformatics 30(9):1312-1313.

WILLIG, M.R., \& PRESLEY, S.J. 2016. Biodiversity and metacommunity structure of animals along altitudinal gradients in tropical montane forests. J. Trop. Ecol. 32(5):421-436. 